\title{
Reproductive Biology of Nile Tilapia, Oreochromis niloticus under the Brackish Water Culture Condition
}

\author{
Nassrin Mashaii*, Farhad Rajabipour, Ahmad Bitaraf, Homayun Hosseinzadeh, Mostafa Sharif Ro- \\ hani, Habib Sarsangi, Mohamad Mohammadi
}

National Research Center of Saline Water Aquatics, Iranian Fisheries Science Research Institute, Agricultural Research, Education and Extension Organization (AREEO), P.O.Box 159, Bafq, Yazd, Iran.

How to cite this paper: Nassrin Mashaii, Farhad Rajabipour, Ahmad Bitaraf, Homayun Hosseinzadeh, Mostafa Sharif Rohani, Habib Sarsangi, Mohamad Mohammadi. (2022) Reproductive Biology of Nile Tilapia, Oreochromis niloticus under the Brackish Water Culture Condition. International Journal of Food Science and Agriculture, 6(1), 4-7.

DOI: 10.26855/ijfsa.2022.03.002

Received: December 3, 2021

Accepted: December 28, 2021

Published: January 11, 2022

*Corresponding author: Nassrin Mashaii, National Research Center of Saline Water Aquatics, Iranian Fisheries Science Research Institute, Agricultural Research, Education and Extension Organization (AREEO), P.O.Box 159, Bafq, Yazd, Iran.

Email: Nassrinmashaii@yahoo.com

\begin{abstract}
Tilapia is one of the most important cultured fish in the world. World production of tilapia is highly increased in recent decades. Reproductive strategies of tilapias cause their ability of living in different aquatic ecosystems. On the other hand, the gap between seed supplies and farmers' demand is one of the most serious limitations for tilapia culturists. Nile tilapia Oreochromis niloticus samples were stocked from September 2009 to January 2011. During the study period, water salinity, temperature, $\mathrm{pH}$ and oxygen saturate were fixed at $11.5 \mathrm{ppt}, 27 \pm 0.5^{\circ} \mathrm{C}$, 7.6-8.1 and 100\%, respectively. Fish were fed using 40\% protein food under 18:6 (L:D) 2500lux light regime. Total length and weight of the spawners, absolute and relative fecundity, egg weight and diameter and spawning intervals were investigated. Pearson correlation coefficient between total length and weight of brooders against absolute and relative fecundity, wet weight of an egg, egg clutch and egg diameter were studied $(\mathrm{p}<0.005)$.
\end{abstract}

\section{Keywords}

Tilapia, reproduction, fecundity, egg diameter and weight

\section{Introduction}

Tilapias are the second cultured fish in the world after carps in recent years and have cultured in more than 135 countries. They have rapidly become one of the most popular seafood items in the world. Nile tilapia, O. niloticus is the most common tilapia widely cultured in many tropical and subtropical countries and consists up to $80 \%$ of cultured tilapias of the world. The more tilapia culture is expanded, the more it becomes vital to produce sufficient amounts of seed to meet the increasing demand of tilapia farmers. The current status of tilapia culture in many countries suggests that there is a gap between seed supplies and farmers' demand. Tilapia seed producers are also usually faced with a number of constraints that limit the management of mass seed production [1-6].

Nile tilapia Oreochromis niloticus samples were entered to Iran in December 2008 for the first time. Studies about the feasibility of introduction of tilapia to inland aquaculture in Iran were begun in National Research Center of Saline Water Aquatics in Yazd province at the center of Iran. The reproductive aspects of tilapias are widely investigated in different parts of globe but it has not any history in Iran. The absolute fecundity and spawning of cultured O. niloticus are measured in the present study. 


\section{Materials and methods}

Nile tilapia, Oreochromis niloticus samples were stocked in six $3 \mathrm{~m}^{3}$ fiberglass tanks from September 2009 to January 2011. During the study period, water salinity, temperature, $\mathrm{pH}$ and oxygen saturate were fixed at $11.5 \mathrm{ppt}, 27 \pm 0.5^{\circ} \mathrm{C}$, 7.6-8.1 and $100 \%$, respectively. Heater was used for heating water only in cold season.

Mean weight of brood stocks were $40 \pm 40 \mathrm{~g}$ at the beginning of the study, stocking density $5 / \mathrm{m}^{3}$ and sex ratio $1: 3$ (M:F). Fish were fed using 40\% protein food under 18:6 (L:D) 2500lux light regime. Elastomere tags were used for recognition of female fish. Total body length and weight of the spawned females were recorded. Total eggs of each spawner in each egg laying were count, also weight and the diameters of at least 25 eggs from each egg clutch were measured.

Means of body length and weight of spawners, absolute and relative fecundity (eggs/g spawner body weight) and mean wet weight of eggs were measured and compared monthly, by HSD Tukey test $(p<0.05)$. Spawning intervals of each spawner were recorded. Pearson correlation coefficient between total length and weight of brooders with absolute and relative fecundity, wet weight of an egg, egg clutch and egg diameter were calculated and compared $(\mathrm{p}<0.005)$.

\section{Results}

Frequencies of total length and weight of about $78 \%$ of brooders was between $21.5-31 \mathrm{~cm}$ and $165-495 \mathrm{~g}$, respectively. Total length of the smallest $O$. niloticus spawned in November 2009 was $17 \mathrm{~cm}$ and total weight was $83.5 \mathrm{~g}$. Spawning occurred rarely in brooders larger than $500 \mathrm{~g}$ and scarcely in brooders heavier than $600 \mathrm{~g}$. Absolute fecundity of the studied samples varied between 50 and 2600 with mean of $853 \pm 25$ eggs per spawner. Monthly means of absolute fecundity increased significantly from 6th months of study, by HSD Tukey test $(\mathrm{p}<0.05)$. Relative fecundity varied from 0.29 to 6.8 with mean of $2.77 \pm 0.13$ eggs/g (Figure 3). Monthly mean of relative fecundity was significantly higher at the first month of spawning, by HSD Tukey test $(p<0.05)$. Mean of wet weight of egg clutches was $4.98 \pm 0.31 \mathrm{~g}$ during the study period with significantly increase from $6^{\text {th }}$ month of the study, by HSD Tukey test $(p<0.05)$. Mean of wet weight of an egg was obtained $0.0062 \pm 0.0001 \mathrm{~g}$. Monthly means of wet weight of tilapia eggs gradually increased during the study period. Diameter of the eggs varied between 1.8 to $3.5 \mathrm{~mm}$ and its mean was $2.58 \pm 0.009 \mathrm{~mm}$ with considerable increase from $6^{\text {th }}$ month of the study. Analysis of Pearson correlation coefficients showed significant positive correlation between total length and weight of the brooders with absolute fecundity, wet weights of an egg and the egg clutch and the diameter of the egg $(\mathrm{p}<0.005)$.

Relative fecundity had significantly negative correlation against total length $(\mathrm{P}=-0.183, \mathrm{~N}=381)$ and body weight $(\mathrm{P}=-0.253, \mathrm{~N}=381)$ of the spawners $(\mathrm{p}<0.005)$. Spawning intervals of the brooders varied between 16 to 34 days.

\section{Discussion}

Results showed brooders with 165-495g weight were more frequent spawners. These samples had 8-20 months age. Larger brooders may be omitted from spawning tanks for better efficiency. Other researchers have shown 6-18 months is the best age range for breeding of female nile tilapias. Fecundity and egg hatching will decrease in older brooders [7].

Various ranges of absolute fecundity are recorded by researchers. 905-7619 eggs in 28-51 cm fish [8], 243-847 eggs in tilapias from Zapata lagoon in Mexique [9], 2408 \pm 70 [10], 305-2000 [11] and lower than 100 up to 3000 eggs [12] in cultured nile tilapias. Different relative fecundity amounts are recorded as $3.12 \pm 0.36[13], 7.2 \pm 0.2$ [10] and 3.05-7.53 eggs/kg [14] in cultured nile tilapias.

As reported by other researchers [15], [16], [17] relative fecundity was significantly higher in smaller brooders at the first months of the study $(\mathrm{p}<0.0005)$. Also, there was negative significant correlation between total length and weight of the brooders and relative fecundity. Variation of fecundity may be resulted from different factors mainly age and size of the brooders, diet and environmental factors [18]. Cultured tilapias maturation occurs sooner than normal condition and produces more eggs as a homeostatic response to the environment [15].

Wet weight of an egg and egg clutch of the studied nile tilapias increased after sixth month of the study significantly related to the total length and weight of the brooders $(\mathrm{p}<0.0005)$. Egg diameter was also related to total length and weight of the brooders $(\mathrm{p}<0.0005)$. Positive correlation of the brooder size and wet weight of the egg is expected and recorded by other researchers [19]. So, selection of larger brooders for spawning may result to higher quality eggs. Age of the brooder is the most important factor influencing the egg size [20]. Also, cultured tilapias produce smaller eggs than normally living tilapia [19].

There are different records about spawning frequency of nile tilapia between 5 days to 6 weeks [21], [5], [20], [22]. Successful reproduction cycles have often 3 to 6 weeks intervals that are closed to reproduction intervals obtained in the present study. Matured female tilapias have different batches of simultaneous ovocytes and are able to spawn frequently in a season [23]. Therefore, tilapia larvae may be available all over the year. However, this leads to nonequal fries [24]. Bringing the eggs out of the mouth of the brooders, high density of brooders before reproduction and replacing brooders 
for resting period may cause more synchronized spawning of females [6], [5], [25]. Spawning frequency in tilapias is seriously influenced by environmental factors. Also, younger nile tilapias often have shorter reproduction cycles. Low protein nutrition regymes cause longer reproduction cycles [9], [26], [20], [27].

\section{References}

[1] Fitzsimmons, K. (2018). Global Developments and Market Trends in Tilapia for 2018. Asian Aquaculture, 2018.

[2] Fitzsimmons, K. (2016). Supply and Demand in Global Tilapia Markets 2015. World Aquaculture Society, Las Vegas.

[3] F.A.O. (2014). The state of world fisheries and aquaculture opportunities and challenges. Rome, 2014.

[4] El-Sayed, A. M. (2006). Tilapia culture. CABI Pub. 277P. https://doi.org/10.1079/9780851990149.0000.

[5] Bhujel, R. C. (2000). A review of strategies for the management of Nile tilapia (Oreochromis niloticus) broodfish in seed production systems, especially hapa-based systems. Aquaculture, 181, 37-59.

[6] Little, D. C., Macintosh, D. J., and Edwards, P. (1993). Improving spawning synchrony in the Nile tilapia, Oreochromis niloticus (L.). Aquaculture and Fisheries Management, 24, 399-405. https://doi.org/10.1111/j.1365-2109.1993.tb00563.x.

[7] Getinet. G. T. (2008). Effects of Maternal Age on Fecundity, Spawning Interval, and Egg Quality of Nile tilapia, Oreochromis niloticus (L.). Journal of the World Aquaculture Society, 39(5), 671-677.

[8] Njiru, M., Ojuok, J. E., Okeyo-Owuor, J. B., Muchiri, M., Ntiba, M. J., and I. G. Cowx. (2006). Some biological aspects and life history strategies of Nile tilapia Oreochromis niloticus (L.) in Lake Victoria, Kenya. African Journal of Ecology, $44,30-37$.

[9] Peña-Mendoza, B., Gómez-Márquez, J. L., Salgado-Ugarte, I. H., and d. Ramírez-Noguera. (2005). Reproductive biology of Oreochromis niloticus (Perciformes: Cichlidae) at Emiliano Zapata dam, Morelos, Mexico. Revista Biologia Tropical, 53(3-4), 515-522.

[10] Campos-Mendoza, A., McAndrew, B. J., Coward, K., and N. Bromage. (2004). Reproductive response of Nile tilapia (Oreochromis niloticus) to photoperiodic manipulation; effects on spawning periodicity, fecundity and egg size. Aquaculture, 231(1-4), 299-314.

[11] Peterson, M. S., Slack, W. T, Brown-Peterson, N. J., and J. L. McDonald. (2004). Reproduction in Nonnative Environments: Establishment of Nile Tilapia, Oreochromis niloticus, in Coastal Mississippi Watersheds. Copeia, 4, 842-849.

[12] de Graaf, G. J., Galemoni, F., and E. A. Huisman. (1999). Reproductive biology of pond reared Nile tilapia, Oreochromis niloticus L. Aquaculture Research, 30, 25-33.

[13] Getinet, G. T. and N. B. Amrit. (2007). Effects of feeding, stocking density and water-flow rate on fecundity, spawning frequency and egg quality of Nile tilapia, Oreochromis niloticus (L.). Aquaculture, 272 (1-4), 380-388.

[14] El-Sayed, A. M., Mansour, C. R., and A. A. Ezzat. (2003). Effects of dietary protein levels on spawning performance of Nile tilapia (Oreochromis niloticus) broodstock reared at different water salinities. Aquaculture, 220, 619-632.

[15] Ahmed, A. A., Abdallaa, M. S., and T. T. George. (2007). Egg Enumeration, incubation, hatchinga and developmenot of the "MiracleF ish", Oreochromis niloticus, in the Sudan. AAC Spec. Publ., 12, 60-64.

[16] Payne, A. I. and R. I. Collinson. (1983). A comparison of the biological characteristics of Sarotherodon aureus (Steindachner) with those of S. niloticus (L.) and other tilapia of the delta and lower Nile. Aquaculture, 30, 335-351.

[17] Peters, H. M. (1983). Fecundity, egg weight and oocyte development in tilapias (Cichlidae, Teleostei). (ICLARM Translations 2). International Center for Living Aquatic Resources Management, Manila, Phillippines, p. 28.

[18] Little, D. C. and G. Hulata. (2000). Strategies for tilapia seed production. In: Tilapias: Biology and Exploitation. Beveridge, M. C. M. and B. J. McAndrew, Editors. Kluwer Academic Publishers, London, UK. Pp. 267-326.

[19] Duponchellea, F., Cecchib, P., Corbinb, D., Nũneza J., and M. Legendre. (2000). Variations in fecundity and egg size of female Nile tilapia, Oreochromis niloticus, from man-made lakes of C^ote d'Ivoire. Environmental Biology of Fishes, 57, 155-170.

[20] Coward, K. and N. R. Bromage. (2000). Reproductive physiology of female tilapia broodstock. Reviews in Fish Biology and Fisheries, 10, 1-25.

[21] Onumah, E. E., Wessels, S., Wildenhayn, N., Brümmer, B., and G. H. Schwark. (2010). Stocking density and photoperiod manipulation in relation to estradiol profile to enhance spawning activity in female Nile tilapia. Turkish Journal of Fisheries and Aquatic Sciences, 10, 463-470.

[22] Macintosh, D. J. and D. C. Little. (1995). Nile tilapia (Oreochromis niloticus). In: Broodstock Management and Egg and Larval Quality, (eds.) N.R. Bromage, and R.J. Roberts, Blackwell Science Publication, University Press, Cambridge, UK, p. 424.

[23] Babiker, M. M. and H. Ibrahim. (1979). Studies on the biology of reproduction in the cichlid Tilapia nilotica (L.): gonadal maturation and fecundity. Journal of Fish Biology, 14, 437-448. 
[24] Fessehaye, Y. (2006). Natural mating in Nile tilapia (Oreochromis niloticus L.) Implications for reproductive success, inbreeding and cannibalism. PhD thesis, Wageningen University, Netherlands. P. 149.

[25] Lovshin, L. L. and H. H. Ibrahim. (1989). Effects of broodstock exchange on Oreochromis niloticus egg and fry production in net enclosures. In: Pullin, R.S.V., Bhukaswan, T., Tonguthai, K., Maclean, J.L. (Eds.), In: The Second International Symposium on Tilapias in Aquaculture, ICLARM, 231-236.

[26] Herbst, E. C. (2002). Induction of tetraploidy in zebrafish danio rerio and Nile tilapia Oreochromis niloticus. M.Sc Thesis, University of North Carolina at Charlotte, USA, p. 127.

[27] Srisakultiew, P. (1993). Studies on the reproductivpe biology of Oreochromis niloticus (L.). PhD thesis, Institute of Aquaculture, Univ. Stirling, UK. 